\title{
PROCEEDINGS
}

OF THE

\section{CAMBRIDGE PHILOSOPHICAL SOCIETY}

\author{
VOL. XXIII \\ PART V \\ (With Plate IV)
}

\begin{abstract}
CAMBRIDGE
AT THE UNIVERSITY PRESS

AND SOLD BY

DEIGHTON, BELL \& CO,, LIMITED, AND BOWES \& BOWES, CAMBRIDGE

CAMBRIDGE UNIVERSITY PRESS, FETTER LANE, LONDON, E.C. 4

1927
\end{abstract}

PRINTED IN GREAT BRITAIN

81 January 1927. 
